\title{
Farklı tuzluluk seviyelerinin bazı kamışsı yumak ( $F$. arundinacea) çeşitlerin çimlenme ve erken fide gelişimi üzerine etkisi
}

Effects of different salinity stress levels on germination and early seedling performance of some tall Fescue (F. arundinacea) species

\author{
Mustafa KIZILşiMŞEK ${ }^{1 \mathscr{A}}$ (D), Eylül Nezahat SÜREN ${ }^{1}$ (D)
}

${ }^{1}$ Kahramanmaraş Sütcü Imam University, Faculty of Agriculture, Department of Field Crops, Onikişubat-Kahramanmaraş, Turkey.

MAKALE BILGISI / ARTICLE INFO

Makale tarihçesi / Article history:

DOI: $10.37908 / \mathrm{mkutbd} .711450$

Geliş tarihi /Received:30.03.2020

Kabul tarihi/Accepted:07.05.2020

\section{Keywords:}

Turf grass, Germination, Salinity, seedling development.

\footnotetext{
Corresponding author: M. KIZILŞIMSŞEK

$\bigotimes: \underline{\text { mkizil@ksu.edu.tr }}$
}

\author{
ÖZET / A BSTRACT
}

Atıf / Citation: Kızılşimşek M, Süren EN (2020) Farklı tuzluluk seviyelerinin bazı kamışsı yumak (F. arundinacea) çeşitlerin çimlenme ve erken fide gelişimi üzerine etkisi. MKU. Tar. Bil. Derg. 25(2) : 189-197. DOI: $10.37908 /$ mkutbd. 711450

\section{GiRiş}

Günümüzde dünyanın bir çok bölgesinde ve ülkemizde hızlı kentleşme sorunu mevcuttur. Özellikle şehirlerin beton yapıları arasında belli ölçüde yeşil alan yapılması, şehirlerin gelişmişliği bakımından da bir ölçü haline gelmiştir. Bu noktada çim bitkilerinin önemi kendini belli etmekte, yoğun kentleşme karşısında önemli bir toplumsal gereksinim olarak karşımıza çıkmaktadır (Altan, 1989; Avcıoğlu, 1997; Kuşvuran ve Tansı, 2009). Çim örtüleri, bulundukları alanlarda hava kirliliğinin önlenmesi, gürültü düzeyinin azaltılması, toz sorununun önemli derecede giderilmesi (Avcıoğlu, 1997), mevcut ortamı serinletmesi (Sencer ve Gökmen, 1996) gibi hayati görevler yapmaktadırlar. Gelişmiş düzeydeki Avrupa ülkelerinde kişi başına düşen yeşil alan miktarı 8-12 $\mathrm{m}^{2}$ iken, ülkemiz için bu rakamın $2 \mathrm{~m}^{2}$ olduğu bilinmektedir. Dünya metropollerinden Rio de Janerio, Paris, Londra, New York ve ìstanbul için yeşil alan oranının sırasıyla; \%29, \%9.4, \%38.4, \%14 ve \%1.5 olması yeşil alanlarımızın ne kadar sınırlı olduğunun açık bir göstergesidir (Sözen ve ark., 1991).

Tuzluluk sorunu, dünyanın her yerinde bitki gelişmesini ve büyümesini negatif bakımdan etkileyen önemli değişkenlerden biri olarak kabul edilebilir. Dünya yüzeyindeki alanın yaklaşık \%10'u tuzluluk sorunu 
yaşanabilecek topraklardan oluşmakta, sulama yapılan alanların ise \%33-50 arasındaki bir bölümü tuzluluktan etkilenmektedir (Carrow ve Duncan 1998; Marcum, 2006). Ülkemizde 1.5 milyon ha alanda az veya çok bir tuzluluk problemi olduğu bildirilmiştir (Aşçı, 2011). Tuzluluk çoğunlukla kurak ve yarı kurak iklim bölgelerinde taban suyunun kapilarite yoluyla toprak yüzeyine çıkması ve ardından buharlaşma sonucunda, toprak yüzeyinde tuzun birikmesi olayı (Richards, 1954) şeklinde tanımlanmaktadır. Bununla birlikte, kullanılan gübreler ve sulama suyunun tuz içermesi gibi faktörler de tuzluluğun diğer nedenleri arasındadır (Manuchehri ve Salehi, 2015).

Yeşil alan bitkileri, azotlu gübre ve su ihtiyacı yüksek olan, bu nedenle sık ve yoğun gübrelenen, özellikle yağışların olmadığı dönemde de oldukça sık bir şekilde sulanan bitkilerdir. Sulama suyu kalitesi kötü olduğunda veya tuz içerdiğinde, yoğun gübre kullanımı ve yaz aylarındaki yoğun buharlaşmanın da etkisiyle, toprakta tuz birikimi de zamanla artmaktadır. Bitki yetişme ortamındaki tuz fazlalığı, osmotik basınç etkisi, iyon toksititesi veya su alımının engellenmesi gibi etkilerle bitkinin gelişmesini ciddi boyutlarda sınırlar ve bitki büyümesini engeller (Ekmekçi ve ark., 2005). Son yıllarda toprak tuzluluğunun ozmotik dengeyi bozduğu ve iyon toksititesine neden olduğu, ancak bazı bitkilerin hücrelerinin turgor değişim miktarını azaltan ve protein bozulmasını önleyen prolin enzimini üreterek bu yan etkileri azalttığı ve tuzluluğa karşı daha tolerant hale geldiği açıklanmıştır (Manuchehri ve Salehi, 2015). Glikofit (tuza duyarlı) bitkiler ile halofit (tuza toleranslı) bitkilerin morfolojik ve fizyolojik yapıları birbirine çok yakındır. Ancak, halofit bitkiler, bünyelerinde tuz adaptasyonu ile ilgili fizyolojik mekanizmaları daha etkin şekilde kullanmaktadır. Tuzluluk problemi bulunan alanlarda veya sulama suyunun belli oranda tuz içermesi durumunda, tuzun yarattığı olumsuz etkilerin giderilmesi için en etkili yöntemlerin başında, tuzluluğa dayanıklı türlerin ve/veya çeşitlerin kullanılması gelmektedir. Nitekim, Suarez ve Olivera (2016) son yıllarda çim alan bitkileri için ıslah çalışmalarının, kuraklık (Barnes ve ark., 2014), gölgeye dayanıklıık (Trappe ve ark., 2011), düşük sıcaklıklara dayanıklılık (Li ve ark., 2010) ve tuzluluğa dayanıklılık (Abogadallah ve ark., 2010) gibi abiyotik stres faktörleri üzerine yoğunlaştığını bildirmiştir.

Islah çalışmaları yanında, mevcut çeşitlerin de abiyotik stres şartlarına karşı gösterdikleri tepkilerin de bilinmesi gereklidir. Bu çalışma, çim alan tesisinde ülkemizde de yaygın olarak kullanılan $F$. arundinacea türlüne ait bazı çeşitlerin farklı tuzluluk seviyelerindeki çimlenme ve gelişme özelliklerini incelemek amacıyla yapılmıştır.

\section{MATERYAL ve YÖNTEM}

Bu araştırma 2017 yılında Kahramanmaraş Sütçü İmam Üniversitesi Ziraat Fakültesi Tarla Bitkileri Bölümü laboratuvarında, tesadüf parselleri deneme desenine göre 3 tekerrürlü olarak yürütülmüştür. Araştırmada kullanılan çim tohumları, merkezi İzmir'de bulunan tedarikçi bir firmadan temin edilmiş olup araştırma kapsamında kamışsı yumak (Festuca arundinacea) türüne ait Starlet, Filippo ve Greenfront çeşitleri bitkisel materyal olarak kullanılmıştır.

Bu çalışma, bazı çim tür ve çeşitlerin farklı tuzluluk seviyelerinde performanslarının araştırılması amacıyla Kahramanmaraş Sütçü İmam Üniversitesi Ziraat Fakültesi Tarla Bitkileri Bölümü laboratuvarlarında, 2017 yıllında tesadüf parselleri deneme desenine göre üç tekerrürlü kurulmuştur. Çalışma kapsamında öncelikle kullanılacak en yüksek doz olan $8 \mathrm{dSm}^{-1}$ yoğunluktaki çözeltiyi elde etmek için, $0.74 \mathrm{~g} \mathrm{KCL}$ (potasyum klorür), $1.47 \mathrm{~g} \mathrm{NaCL}$ (sodyum klorür), $1.4 \mathrm{~g}$ $\mathrm{CaCL}$ (kalsiyum klorür) ve $2.03 \mathrm{~g} \mathrm{MgCL}$ (magnezyum klorür) yeteri kadar saf su ile karıştırılmıştır. Söz konusu tuz kaynaklarının seçiminde, tarımsal alanlarda ve sulama sularında en çok bulunan tuz türleri dikkate alınmıştır. Elde edilen bu çözelti stok çözelti olarak ele alınmış ve $\mathrm{EC}_{1} * \mathrm{ML}_{1}=\mathrm{EC}_{2} * \mathrm{ML}_{2}$ formülüne göre, $\% 50$ seyreltilerek $4 \mathrm{dSm}^{-1}$ yoğunluğu elde dilmiştir. Çözeltilerin 4 ve $8 \mathrm{dSm}^{-1}$ değerlerine ulaştığını ölçmek için, EC (elektriksel iletkenlik ) ölçüm cihazı kullanılmıştır.

Çalışma kapsamında $9 \mathrm{~cm}$ çapında petrilere uygun şekilde iki kat kurutma kağıdı kesilerek petrilerin altına konulmuştur. Her petriye 25 'şer tohum konulup üzerine uygun çözeltilerden $5 \mathrm{ml}$ ilave edilmiştir. Petri kabında bulunan çözeltinin buharlaşarak tuz konsantrasyonunda değişikliğe neden olmaması amacıyla tüm petri kaplarının kapakları konulduktan sonra etrafı parafilm ile kapatılmış ve $15^{\circ} \mathrm{C}^{\prime}$ ye ayarlanan çimlendirme dolabına konulmuştur. Çimlendirme dolabındaki petriler 3 günde bir incelenmiş, her bir petride çimlenen bitki sayısı kaydedilmiştir ve eksilen çimlendirme suları uygun konsantrasyonlarda ilave edilmiştir. Çimlendirmenin 12. gününde, çimlenen bitkiler sayılmış ve petrideki toplam tohum sayısına oranlanarak çimlenme oranı hesaplanmıştır. Ayrıca, 12. günün sonunda, her bir uygulamaya ait petri kaplarından tesadüfen alınan 10 fidede, fide boyu, plumula boyu ve radikula boyu cetvel yardımı ile $\mathrm{mm}$ cinsinden ölçülmüş ve ortalaması alınarak hesaplanmıştır. Aynı 10 fidenin üzerinde kalan tohum kavuzları ayrılarak alındıktan sonra, $0.0001 \mathrm{~g}$ hassasiyetli terazide tartılıp 10'a bölünerek, fide yaş ağırlığı değeri bulunmuştur. Daha 
sonra 10 fide, kök boğazından jilet ile kesilerek, plumula ve radikula kısımlarına ayrılmış ve yaş plumula ve radikula ağırlıkları aynı yöntemle belirlenmiştir. Örnekler kurutma kağıtları arasına konularak, $78^{\circ} \mathrm{C}^{\prime} \mathrm{de}$ 48 saat kurutulduktan sonra desikatöre alınmış ve tekrar tartılarak kuru plumula ve kuru radikula ağırlıkları belirlenmiştir. Bu ağırlıklar toplanarak fide kuru ağırlığı hesaplanmıştır. Elde edilen veriler, SAS istatistik paket programı kullanılarak Tesadüf Parsellerinde Faktöriyel Düzenleme deneme desenine göre varyans analizine tabi tutulmuş, aralarındaki farkların önemli olduğu $(P<0.05)$ ortalamalar ise LSD testi ile gruplandırımıştır.

\section{BULGULAR ve TARTIŞMA}

Fide, Plumula ve Radikula Uzunluğu, Yaş ve Kuru Ağırlı̆̆ı

F. arundinacea çeşitlerinin farklı tuzluluk derecelerindeki fide, radikula ve plumula uzunluklarına ile yaş ve kuru ağırlıklarına ait ortalama değerler ve oluşan gruplar Çizelge $1^{\prime}$ de verilmiştir. Tuzluluk derecelerinin $F$. arundinacea çeşitlerinin incelenen tüm özellikleri üzerine istatistiksel olarak önemli etkilerde bulunduğu belirlenmiştir. Çeşitler arasındaki farklılığın ise, fide ve plumula boyu ile fide ve plumula kuru ağırlık özelikleri bakımından önemli olduğu, diğer özellikler bakımından çeşitler arasında önemli bir farklılığın bulunmadığı belirlenmiştir.

F. arundinacea çeşitlerinin fide boyu, plumula boyu ve radikula boyu bakımından en yüksek değerlerin sırasıyla 98.67, 47.91 ve $50.64 \mathrm{~mm}$ ile kontrol uygulamasından elde edildiği, en düşük derecede tuz uygulamasının bile her üç özellik üzerinde önemli olumsuz etkilerde bulunduğu görülmüştür (Çizelge 1). Özellikle $8 \mathrm{dSm}^{-1}$ uygulamasında söz konusu değerler aşırı derecede azalmıştır.

Hafif tuzluluk derecesi olan $4 \mathrm{dSm}^{-1}$ seviyesinde bile fide boyu, plumula boyu ve radikula boyu değerlerinin kontrol grubuna göre, sırasıyla \%75.69, \%69.09 ve \%81.87 oranında azaldığı belirlenmiştir. Bu durumda tuzluluk şartlarında kök sisteminin toprak üstü aksama göre çok daha fazla miktarda olumsuz etkilendiği söylenebilir. Tuza tolerans bakımından en öncelikli parametrelerden birisi bitkinin radikula gelişimidir. Çimlenme esnasında bitkinin bünyesine su alımına engel olan tuzluluk sorunu yoksa, bitki kök sistemi normal bir gelişim gösterir. Tuz stresine maruz kalan bitkilerin gelişimi, su alımında sorun yaşadıkları için olumsuz etkilenmektedir. Nitekim Atak ve Çiftçi (2006) ile Kara ve ark. (2011) tuzluluğun özellikle radikula gelişimini olumsuz etkilediğini bildirmişlerdir. Benzer şekilde Gao ve Li (2014), tuzluluk uygulaması ile $F$. arundinacea bitkisinin sap ve kök biyomasını kontrol uygulamasına kıyasla sırasıyla \%58 ve \%63 oranında azaldığını, tuzluluğun kök gelişimini daha çok engellediğini bildirmiştir.

Starlet çeşidi fide $(54.46 \mathrm{~mm}$ ) ve plumula boyu ( 29.74 $\mathrm{mm}$ ) değerleri ile çeşitler arasında en yüksek değerlere sahip olmuş, bunu önemsiz bir farklılıkla Greenfront çeşidi izlemiştir. Flippo çeşidinin ise en düşük değerlere sahip olduğu görülmektedir. Radikula boyu bakımından her ne kadar çeşitler arasındaki farklılık istatistiksel olarak önemli olmasa da, diğer iki özellikteki gibi, Starlet çeşidi en yüksek değere, Flippo çeşidi ise en düşük değere sahip olmuştur. $F$. arundinacea çeşitlerinin özellikle fide ve plumula boyu bakımından tuzluluk derecelerine tepkilerinin birbirinden farklı olduğu da söylenebilir. Kuşvuran ve ark. (2014), farklı F. arundinacea çeşitlerinin farklı tuz konsantrasyonlarındaki çimlenme ve fide gelişimi üzerine yaptıkları çalışmalarında, tuz uygulamasıyla birlikte tüm çeşitlerin çimlenme oranlarının, plumula ve radikula uzunluğunun önemli ölçüde azaldığını, ancak bu azalmaların tuz derecesine ve çeşide bağlı olarak değişkenlik gösterdiğini bildirmişlerdir.

Farklı tuzluluk derecelerinin radikula yaş ağırlığı değerlerini çok ciddi düzeyde azalttığı görülmektedir. En yüksek radikula yaş ağırlığı $4.52 \mathrm{mg} /$ fide ile kontrol parselinden elde edilirken, en düşük tuz uygulaması olan $4 \mathrm{dSm}^{-1}$ uygulamasında bile bu değerin \%93.85 oranında azalarak $0.28 \mathrm{mg} /$ fide seviyesine düştüğü saptanmıştır. Fide, plumula ve radikula yaş ağırlıkları bakımından çeşitlerin tuzluluk derecelerine verdiği tepkiler ise birbirinden farklı bulunmamıştır.

Fide kuru ağırlığı değerleri bakımından hem çeşitler arasında hem de tuzluluk seviyeleri bakımından önemli farklııkların bulunduğu Çizelge 1 'den izlenmektedir. Uygulanan tuzluluk seviyesi arttıkça, fide kuru ağırlığı değerinin çok önemli bir şekilde azaldığı görülmektedir. En yüksek fide kuru ağırlığı değeri Starlet çeşidinden elde edilmiş, bunu önemsiz bir farklılıkla Greenfront çeşidi izlemiş, en düşük değer ise Flippo çeşidinden elde edilmiştir (Çizelge 1).

Farklı tuzluluk seviyelerinde çimlendirilen $F$. arundinacea çeşitlerinin ortalama fide yaş ağırlığı değerleri incelendiğinde, tuzluluk seviyeleri arasındaki farklılığın önemli olduğu, en yüksek değerin 15.50 $\mathrm{mg} /$ fide ile kontrol uygulamasından elde edildiği, tuzluluk arttıkça bu değerin önemli ölçüde azaldığı ve en düşük değerin $0.34 \mathrm{mg} /$ fide ile $8 \mathrm{dSm}^{-1}$ tuzluluk uygulamasından elde edildiği belirlenmiştir (Çizelge 1 ). Ortalama plumula yaş ağırlığı değerleri üzerine tuzluluk derecelerinin önemli etkilerinin bulunduğu, hafif derecede tuzluluğun bile $\left(4 \mathrm{dSm}^{-1}\right) \quad F$. arundinacea 
çeşitlerinin plumula yaş ağırlığı üzerine çok önemli olumsuz etkilerinin olduğu ve plumula yaş ağırlığının kontrol uygulamasına göre \%95.76 düzeyinde azaldığı saptanmıştır. Demiroğlu Topçu ve ark. (2016), Ertekin ve ark. (2017) ve Ertekin ve ark. (2018) tuz dozu arttıkça bitkilerin kleoptil boyunun kısaldığını ve yaş ağılıklarının da önemli derecede azaldığını bildirmişlerdir. Fide ve plumula yaş ağırlığı değerleri bakımından çeşitler arasında önemli bir farklılık bulunmamıştır.

Çizelge 1. Farklı tuzluluk derecelerinde çimlendirilen F. arundinacea çeşitlerinin ortalama fide, plumula ve radikula uzunlukları, yaş ağırlıkları, kuru ağırlıkları ve oluşan gruplar

Table 1. Mean seedling, shoot and root length and statistical groups of F. arundinacea germinated at differnet salt concentration

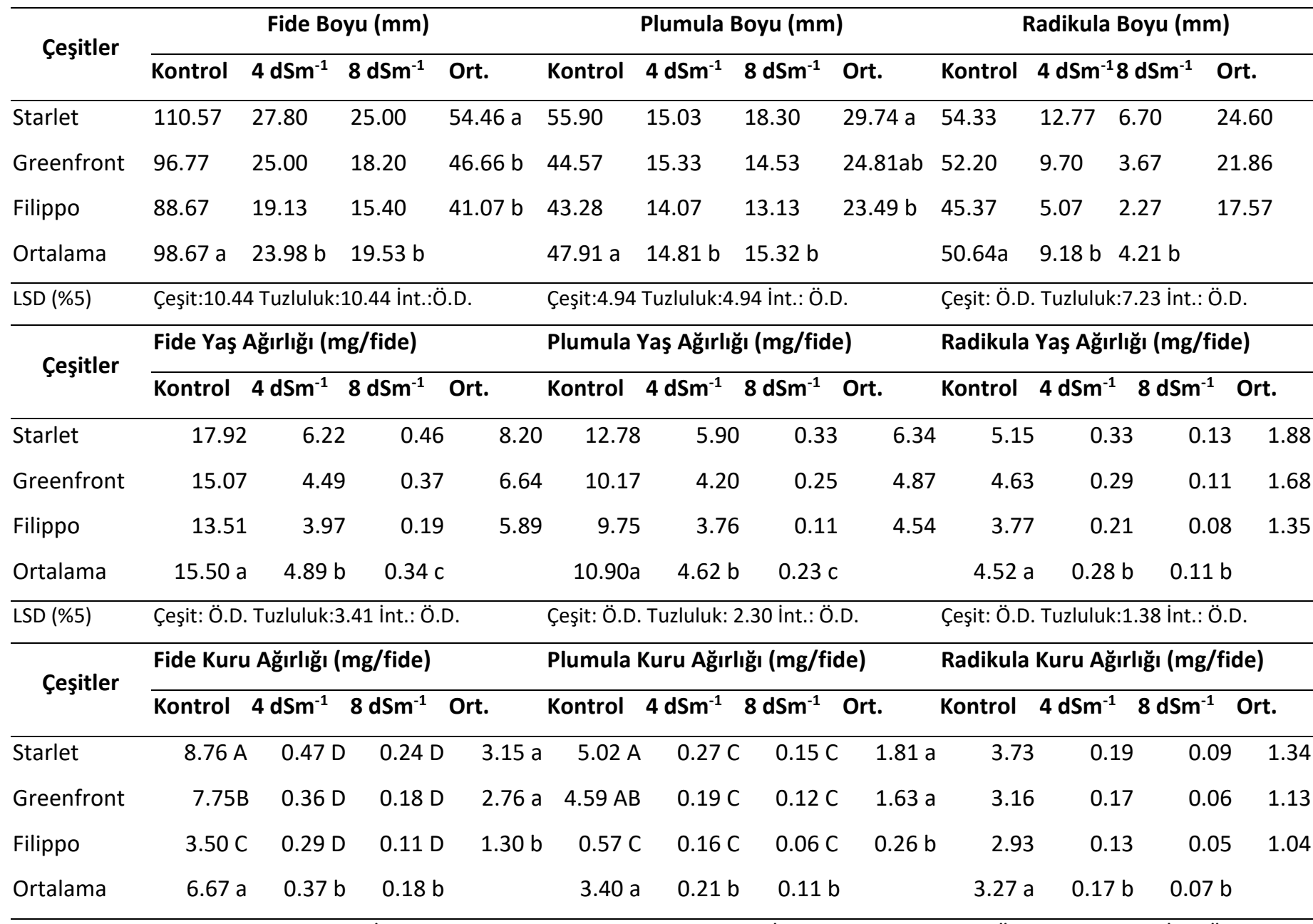

LSD (\%5) Çeşit:0.39 Tuzluluk:0.39 İnt.:0.69 Çeşit: 0.42 Tuzluluk:0.42 Int.: $0.71 \quad$ Çeşit: Ö.D. Tuzluluk:0.38 İnt.: Ö.D.

Ö.D.: Önemli değil. İnt.: İnteraksiyon. Ort.: Ortalama

Kuşvuran ve ark. (2014), yaptıkları çalışmada, F. arundinacea çeşitlerinin plumula yaş ağırlığının tuzluluk derecelerinden önemli derecede etkilendiğini, çeşitler arasında da bu özellik bakımından önemli farklılıklar bulunduğunu bildirmişlerdir.

Fide kuru ağırlık değerleri bakımından $F$. arundinaceae çeşitleri ile tuzluluk uygulamalarının etkileri arasında önemli bir interaksiyon tespit edilmiş olup, bu interaksiyona ait grafik Şekil 1'de gösterilmiştir.
Araştırmada kullanılan $F$. arundinacea çeşitlerinin fide kuru ağırlığı değerleri bakımından farklı tuzluluk seviyelerine farklı tepkiler verdiği, bu nedenle bir Çeşit $\mathrm{x}$ Tuzluluk interaksiyonunun oluştuğu belirlenmiştir. Çeşitlerin farklı tuzluluk derecelerine farklı tepkiler verdiği Şekil 1 'den izlenmektedir. Kontrol uygulamasında çeşitlerin fide kuru ağırlık değerleri bakımından büyük farklılıklar gösterdiği, buna karşılık, 4 $\mathrm{dSm}^{-1}$ ve $8 \mathrm{dSm}^{-1}$ tuzluluk uygulamalarında tüm çeşitlerin birbirine oldukça yakın değerlere sahip olduğu 
görülmektedir. Diğer bir ifadeyle kontrol uygulamasında çeşitler birbirlerinden farklı tepkiler ortaya koyarken, tüm tuzluluk uygulamalarında birbirlerine benzer sonuçlar ortaya çıkarmışlardır. Çeşitlerin, kontrol uygulamasında birbirlerinden oldukça farklı, tuzluluk şartlarında ise birbirine benzer sonuçlar üretmesi, bir interaksiyona neden olmuştur.
Plumula kuru ağırlıkları bakımından hem çeşitler hem de tuzluluk dereceleri arasında önemli farklılıklar bulunmuştur. Starlet çeşidi, diğer bir çok özellikte olduğu gibi, plumula kuru ağırlığı bakımından da en yüksek değerlere sahip olmuştur.

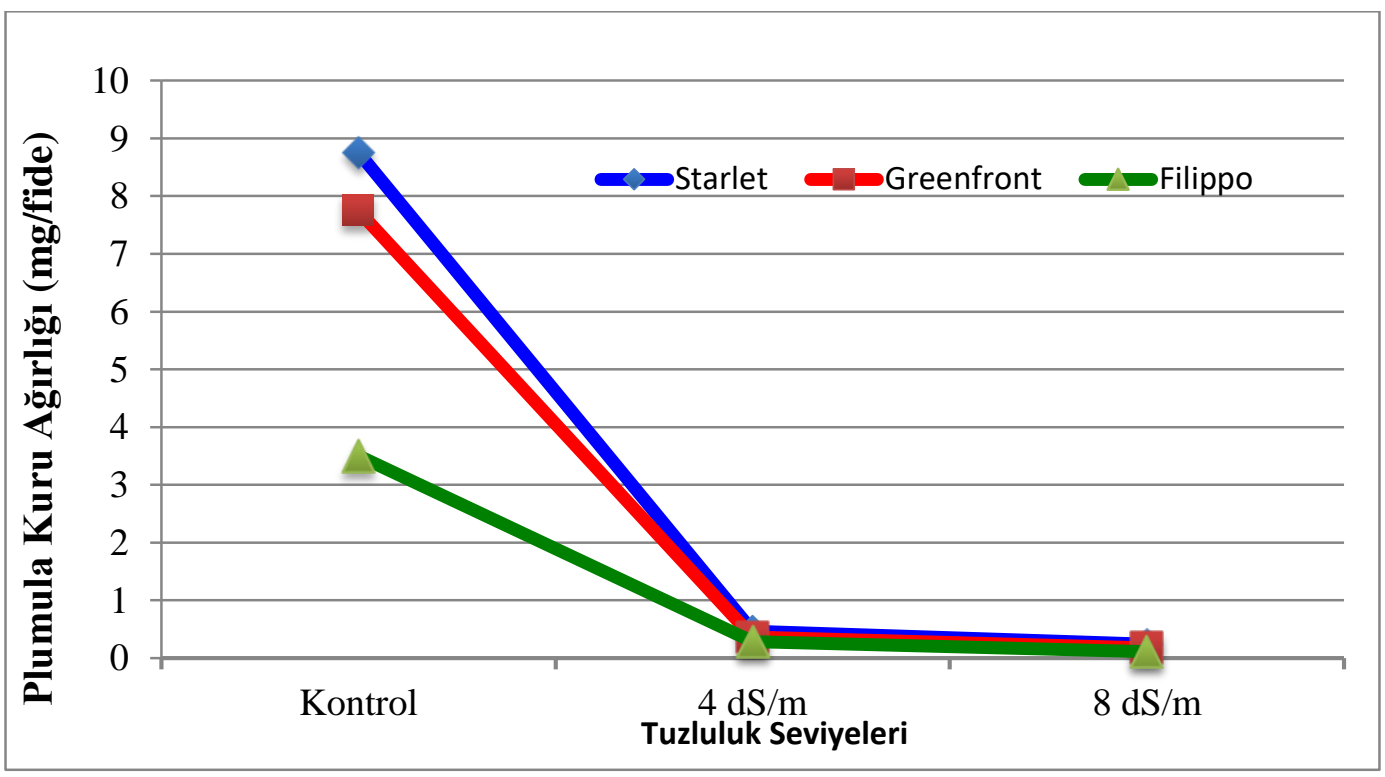

Şekil 1. Farklı tuzluluk seviyeleri uygulanmış $F$. arundinacea çeşitlerinin fide kuru ağırlığına ilişkin çeşit x tuzluluk interaksiyonu

Figure 1. Cultivar and salt concentration interactions relating to seedling dry weight of F. arundinacea cultivars germinated at differnet salt concentrations

Tuzluluk uygulamaları bakımından en yüksek Plumula kuru ağırlı̆̆ı değerlerinin $3.40 \mathrm{mg} /$ fide ile kontrol uygulamasından elde edildiği, bunu önemli bir farklılıkla ve 0.21 ve $0.11 \mathrm{mg} /$ fide değerleri ile sırasıyla $4 \mathrm{dSm}^{-1}$ ve $8 \mathrm{dSm}^{-1}$ uygulamalarının izlediği belirlenmiştir. Araştırma verilerine dayanarak, Plumula kuru ağırlı̆ı bakımından F. arundinacea çeşitleri arasında önemli farklılıklar bulunduğu ancak, tüm çeşitlerin hafif tuzluluk derecelerinden bile ciddi düzeyde etkilendiği, tuzluluğun özellikle kök gelişimini daha fazla engellediği belirlenmiştir. Benzer bir sonuç, Gao ve Li (2014)'nın
F.arundinacea ile yaptıkları çalışmadan da elde edilmiştir. Bununla birlikte, tuzluluğun genellikle bitkilerin toprak üstü aksamlarını, toprak altı aksamlarından daha fazla etkilediğini bildiren çalışmalar da mevcuttur (Pawlowicz ve ark., 2018).

Plumula kuru ağırlık değerleri bakımından $F$. arundinacea çeşitlerinin performansları ile tuzluluk uygulamalarının etkileri arasında önemli bir interaksiyon bulunduğu saptanmış ve bu interaksiyona ilişkin veriler Şekil 2'de gösterilmiştir. 


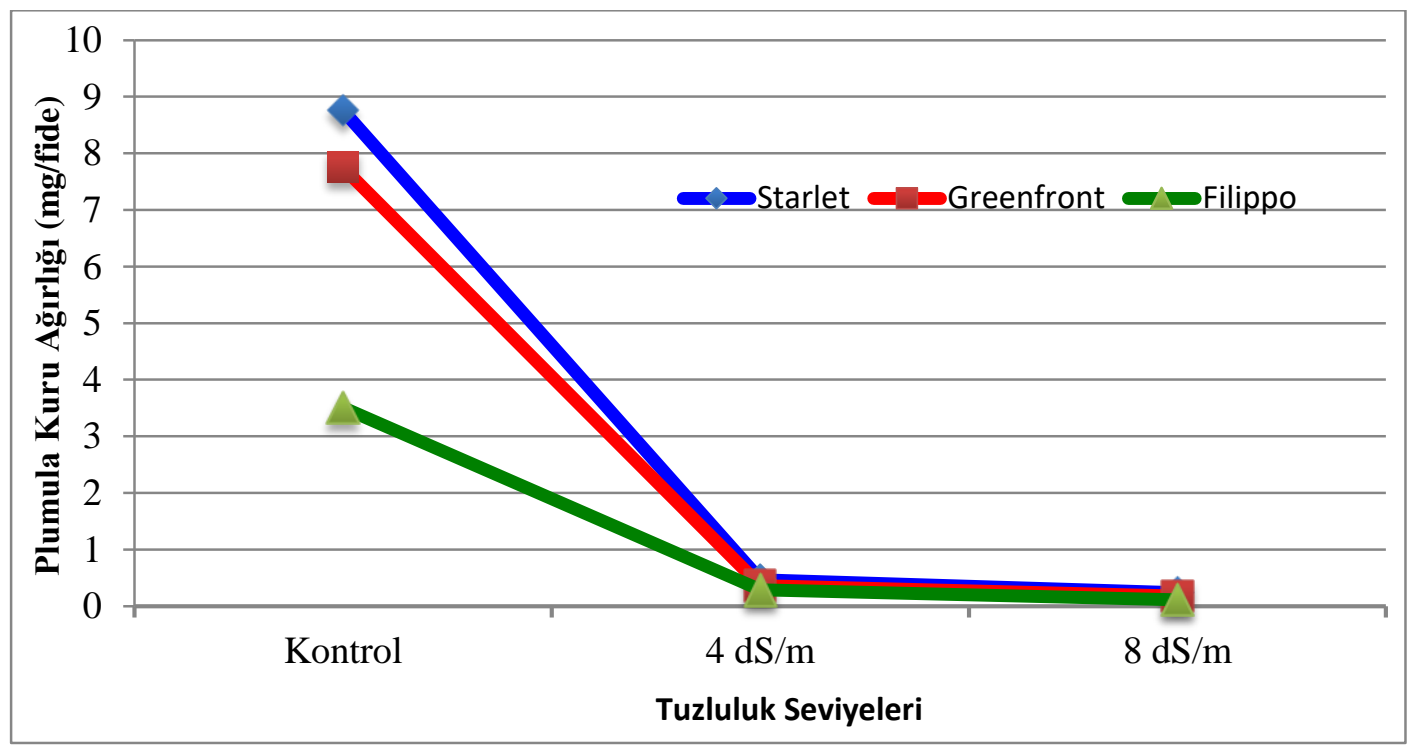

Şekil 2. Farklı tuzluluk seviyeleri uygulanmış $F$. arundinacea çeşitlerinin plumula kuru ağırlığına ilişkin çeşit x tuzluluk interaksiyonu

Figure 2. Cultivar and salt concentration interactions relating to shoot dry weight of $F$. arundinacea cultivars germinated at differnet salt concentrations

Araştırmada kullanılan F. arundinacea çeşitlerinin plumula kuru ağırlığı değerleri bakımından farklı tuzluluk seviyelerine farklı tepkiler verdiği ve bu nedenle bir Çeşit $x$ Tuzluluk interaksiyonunun oluştuğu belirlenmiştir. Kontrol uygulamasında plumula kuru ağırlıkları bakımından çeşitler arasında büyük farklılıklar bulunduğu, ancak $4 \mathrm{dSm}^{-1}$ ve $8 \mathrm{dSm}^{-1}$ tuzluluk seviyelerinde çeşitlerin benzer tepkiler verdiği görülmektedir. Kontrol uygulamasında en yüksek ve en düşük plumula kuru ağırlık değerlerine sahip çeşitler arasında \%88.65'lik bir farklılık bulunurken, $4 \mathrm{dSm}^{-1}$ ve 8 $\mathrm{dSm}^{-1}$ tuzluluk uygulamalarında bu değer sırasıyla \%42.49 ve \%59.18 olarak gerçekleşmiştir. Yani kontrol uygulamasında çeşitler arasında var olan bu büyük farklıık, tuzluluk uygulamalarında büyük ölçüde ortadan kalkmıştır. Bu nedenle istatistiksel olarak önemli bir Çeşit x Tuzluluk interaksiyonu ortaya çıkmıştır.

Radikula kuru ağırlık değerleri bakımından $F$. arundinacea çeşitleri arasında önemli bir farklılık bulunmadığı, ancak tuzluluk derecelerinin bu özelliğe ilişkin değerleri önemli derecede etkilediği belirlenmiştir. En yüksek radikula kuru ağırlık değerinin $3.27 \mathrm{mg} /$ fide ile herhangi bir tuzluluk uygulamasının yapılmadığı kontrol uygulamasından elde edildiği, en düşük tuzluluk seviyesi olan $4 \mathrm{dSm}^{-1}$ uygulamasında ise bu değerin \%94 oranında azalarak $0.17 \mathrm{mg} /$ fide düzeyine kadar düştüğü saptanmıştır. Kaplan ve ark. (2017), tuzluluk stresi altındaki F. arundinacea bitkisinin gelişiminde çok önemli azalmalar olduğunu, verimin düştüğünü, tuzluluk şiddetinin $8 \mathrm{dSm}^{-1}$ seviyesine çıkmasıyla, verimin $\% 30$ oranında azaldığını bildirmişlerdir.

\section{Çimlenme Oranı}

Farklı F. arundinacea çeşitlerinin farklı tuzluluk derecelerindeki ortalama çimlenme oranı değerleri ve oluşan gruplar Çizelge 2'de verilmiştir.

Çizelge 2. Farklı tuzluluk derecelerinde çimlendirilen F. arundinacea çeşitlerinin ortalama çimlenme oranı (\%) değerleri ve oluşan gruplar

Table 2. Mean germination rate and statistical groups of $F$. arundinacea germinated at differnet salt concentration

\begin{tabular}{|c|c|c|c|c|}
\hline \multirow[t]{2}{*}{ Çeşitler } & \multicolumn{3}{|c|}{ Tuzluluk } & \multirow[t]{2}{*}{ Ortalama } \\
\hline & Kontrol & $4 \mathrm{dSm}^{-1}$ & $8 \mathrm{dSm}^{-1}$ & \\
\hline Starlet & $93.33 \mathrm{~A}$ & $44.00 \mathrm{~B}$ & $16.00 \mathrm{CD}$ & $51.11 \mathrm{a}$ \\
\hline Greenfront & $89.33 \mathrm{~A}$ & $28.00 \mathrm{BC}$ & $8.00 \mathrm{CD}$ & $41.78 \mathrm{a}$ \\
\hline Flippo & $28.00 \mathrm{BC}$ & $5.33 \mathrm{D}$ & $4.00 \mathrm{D}$ & $12.44 \mathrm{~b}$ \\
\hline Ortalama & $93.33 \mathrm{a}$ & $44.00 \mathrm{~b}$ & $16.00 \mathrm{c}$ & \\
\hline
\end{tabular}

LSD: Çeşit: 12.60 Tuzluluk:12.60 int:22.01

Int.: Interaksiyon 
Farklı tuzluluk seviyelerinde $F$. arundinacea çeşitlerinin ortalama çimlenme oranlarının verildiği Çizelge 2'den, en yüksek çimlenme oranının \%51.11 ile Starlet çeşidinden elde edildiği, bunu önemsiz bir farklılıkla Greenfront çeşidinin izlediği, en düşük değerin ise \%12.44 ile Filippo çeşidinden elde edildiği izlenmektedir. Aynı çizelgeden tuzluluk seviyelerinin çimlenme oranı üzerine etkileri incelendiğinde, en yüksek değerin \%93.33 ile kontrol uygulamasından elde edildiği, tuzluluk seviyesi arttıkça çimlenme oranının önemli ölçüde azaldığı ve en düşük çimlenme oranının $\% 16,00$ ile $8 \mathrm{dSm}^{-1}$ seviyesindeki tuzluluktan elde edildiği görülmektedir. Bu bilgiler doğrultusunda, bulgularımız, artan tuz konsantrasyonlarına bağlı olarak çimlenme yüzdelerinin azaldığını bildiren birçok araştırıcının bulguları ile benzerlik göstermekte olup, önceki çalışmaların bir çoğu, bu çalışmanın sonuçlarını destekler niteliktedir (Akgün ve ark., 2011; Kara ve ark., 2011; Ertekin ve ark., 2017; Ertekin ve ark., 2018).

Bununla birlikte, çimlenme oranı bakımından farklı çeşitlerin farklı tuzluluk seviyelerine farklı tepkiler verdiği, bu nedenle bir Çeşit $x$ Tuzluluk interaksiyonunun oluştuğu belirlenmiştir. Bu interaksiyona ait veriler Şekil 3'de gösterilmiştir.

$F$. arundinacea çeşitlerinin farklı tuzluluk derecelerindeki çimlenme oranlarına ilişkin Çeşit $x$
Tuzluluk interaksiyon grafiği incelendiğinde, tüm çeşitlerin çimlenme oranlarının artan tuzluluktan olumsuz etkilendiği, ancak bu etkilenme seviyelerinin çeşitten çeşide farklılık gösterdiği görülmektedir. Nitekim Starlet, Greenfront ve Filippo çeşitlerinde en yüksek çimlenme oranları Kontrol uygulamasında elde edilmiş, $4 \mathrm{dSm}^{-1}$ tuz uygulamasında tüm çeşitlerin çimlenme oranları azalmış, ancak kontrol uygulamasına göre azalmalar anılan çeşitleri için sırasıyla \%52.85, $\% 68.65$ ve $\% 80.96$ düzeyinde olmuştur. Çeşitlerin 8 $\mathrm{dSm}^{-1}$ seviyesindeki çimlenme oranları azalmaya devam etmiş, bir önceki uygulamaya kıyasla Starlet, Greenfront ve Filippo çeşitleri için azalmalar sırasıyla \%63.63, $\% 71.42$ ve $\% 24.95$ düzeyinde gerçekleşmiştir. Bu durumda, $4 \mathrm{dSm}^{-1}$ seviyesindeki tuzluluk uygulamasından en az etkilenen çeşit Starlet, en fazla etkilenen çeşit ise Filippo olurken, $8 \mathrm{dSm}^{-1}$ seviyesinde ise en az etkilenen çeşit Filippo, en fazla etkilenen çeşit de Greenfront olmuştur. Çeşitlerin farklı Tuzluluk derecelerine farklı tepkiler vermiş olması bir Çeşit $x$ Tuzluluk interaksiyonunu ortaya çıkarmıştır. Gao ve Li (2014), 2 farklı F. arundinacea çeşidi ile yaptıkları tuzluluk çalışmasında, çeşitlerin tuz konsantrasyonlarına farklı tepkiler verdiğini ve gelişimlerinde de farklılıklar olduğunu bildirmişlerdir.

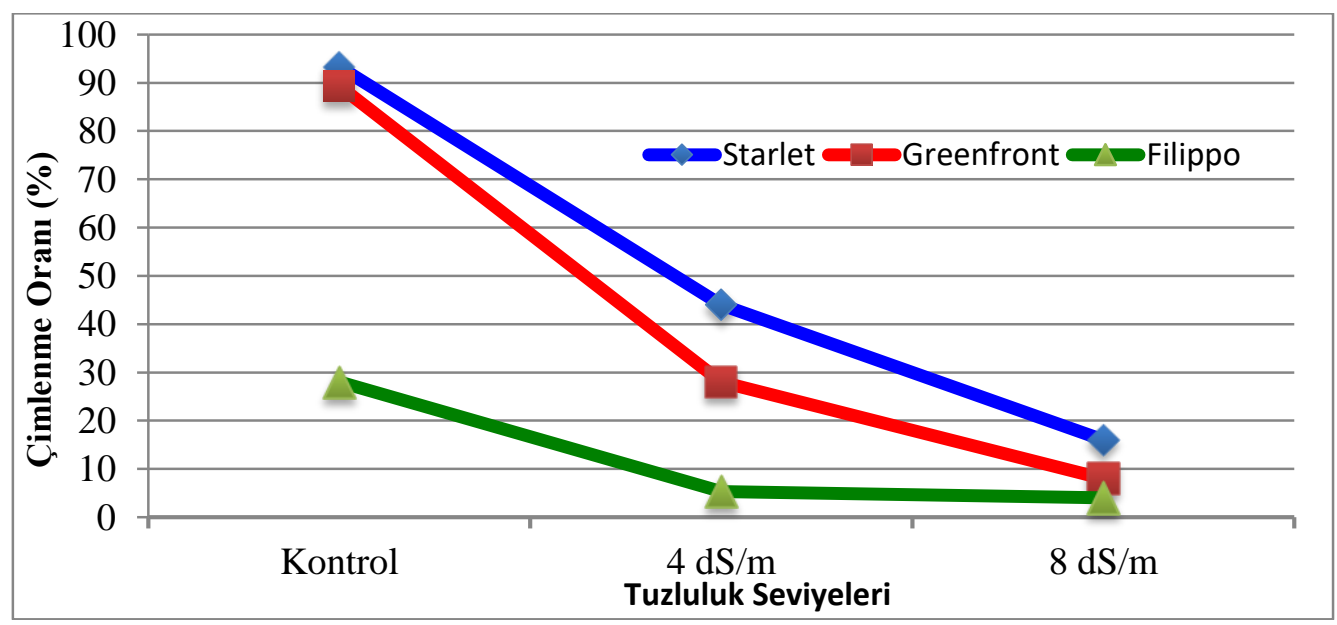

Şekil 3. Farklı tuzluluk seviyeleri uygulanmış $F$. arundinacea çeşitlerinin çimlenme oranına ilişkin çeşit $x$ tuzluluk interaksiyonu

Figure 3. Cultivar and salt concentration interactions relating to germination rate of $F$. arundinacea cultivars germinated at differnet salt concentrations

Farklı tuzluluk derecelerinin $F$. arundinacea çeşitlerinin çimlenme performansları üzerine etkilerinin incelendiği bu çalışmada, incelenen her bir özellik için, tüm çeşitlerde en yüksek değerlere hiç bir tuzluluğun uygulanmadığı Kontrol grubunda ulaşılmıştır. Hafif derecede tuzluluk uygulamalarında bile tüm çeşitlerde incelenen fide özelliklerinde ve çimlenme oranlarında oldukça yüksek miktarda azalmalar görülmüştür. Bu nedenle, $F$. arundinacea türünün anılan çeşitlerinin tuz stresine karşı çok hassas oldukları belirlenmiştir. Bu durumda, hafif veya orta derecede tuzluluk sorunu bulunan alanlarda veya sulama suyu tuz içeren durumlarda, bu çeşitlerin yeşil alan tesisinde kullanılması uygun değildir. 


\section{ÖZET}

Amaç: Bu araştırma bazı çim tür ve çeşitlerinin farklı tuz konsantrasyonlarındaki performanslarının saptanması amacıyla laboratuvar şartlarında yürütülmüştür. Denemede bitki materyali olarak kamışsı yumak (Festuca arundinacea) türüne ait 3 çeşit (Starlet, Filippo ve Greenfront) bitkisel materyal olarak kullanılmıştır.

Yöntem ve Bulgular: Araştırmada farklı tuzluluk konsantrasyonu oluşturmak için $\mathrm{KCl}, \mathrm{NaCl}, \mathrm{MgCl}_{2}$ ve $\mathrm{CaCl}_{2}$ kullanılarak stok çözelti hazırlanmıştır. Kontrol uygulaması ile birlikte, 2 farklı elektriksel iletkenliğe (EC) sahip tuzluluk dozları (4 ve $8 \mathrm{dSm}^{-1}$ ) çimlenme ortamında kullanılmıştır. Araştırmada fide boyu, fide radikula (kök) boyu, fide plumula (sap) boyu, fide yaş ağırlığı, fide radikula (kök) yaş ağırlığı, fide plumula (sap) yaş ağırlığı, fide kuru ağırlığı, fide radikula (kök) kuru ağırlığı, fide plumula (sap) kuru ağırlığı ve çimlenme oranı özellikleri incelenmiştir.

Genel Yorum: Elde edilen sonuçlardan Festuca türüne ait çeşitlerin hafif ve orta derecede tuzluluk seviyelerine bile tolerans göstermediği belirlenmiştir.

Çalışmanın Önemi ve Etkisi: Festuca türüne ait çeşitlerin üzerinde olan bu tuz stresi çalışması yeşil alan tesisinde yol gösterici olması amacıyla yürütülmüştür. $\mathrm{Bu}$ çalışma ileriki çalışmalara kaynak oluşturma niteliğindedir.

Anahtar Kelimeler: Çim bitkileri, çimlenme, tuzluluk, fide gelişimi.

\section{ÇIKAR ÇATIŞMA BEYANI}

Yazar(lar) çalışma konusunda çıkar çatışmasının olmadığını beyan eder.

\section{ARAŞTIRMACILARIN KATKI ORANI BEYANI}

Yazarlar çalışmaya eşit oranda katkı sağlamış olduklarını beyan eder.

\section{KAYNAKLAR}

Abogadallah GM, Serag MM, El-Katouny TM, Quick WP (2010) Salt tolerance at germination and vegetative growth involves different mechanisms in barnyard grass (Echinochloa crusgalli L.) mutants. Plant Growth Regul. 60(1):1-12.

Akgün I, Kara K, Altındal D (2011) Effect of salinity $(\mathrm{NaCl})$ on germination, seedling growth and nutrient uptake of different triticale genotypes. Turk. J. Field Crops 16 (2): 225-232.

Altan S (1989) PM Yerörtücüleri, Çukurova Üniversitesi Ziraat Fakültesi Ders Kitabı No:108, Adana.
Aşcı OO (2011) Salt tolerance in red clover (Trifolium pratense L.) seedlings. Afr. J. Biotechnol. 10(44): 8774-8781.

Atak M, Çiftçi CY (2006) Bazı tritikale çeşit ve hatlarının morfolojik karakterizasyonu. Ankara Üniversitesi Ziraat Fakültesi Tarım Bilimleri Dergisi 12(1): 101111.

Avcıoğlu R (1997) Çim tekniği yeşil alanların ekimi dikimi ve bakımı. Ege Üniversitesi Ziraat Fakültesi Tarla Bitkileri Bölümü İzmir. 269s.

Barnes BD, Kopecký D, Lukaszewski AJ, Baird JH (2014) Evaluation of turf-type interspecific hybrids of meadow fescue with perennial ryegrass for improved stress tolerance. Crop Sci. 54(1): 355-365.

Carrow RN, Duncan RR (1998) Salt affected turfgrass sites: Assessment and management. Ann Arbor Press, Chelsea.

Demiroğlu Topçu G, Çelen AE, Kuru E, Özkan ŞS (2016) Farklı tuz konsantrasyonlarının kamışsı yumak (Festuca arundinacea) ve mavi ayrık (Agropyron intermedium) bitkilerinin çimlenme ve erken gelişme dönemlerindeki etkileri üzerine bir araştırma. Tarla Bitkileri Merkez Araştırma Enstitüsü Dergisi 25 (Özel Sayı) 219-224.

Ekmekçi E, Apan M, Kata T (2005) Tuzluluğun bitki gelişimine etkisi. Ondokuzmayıs Üniversitesi Ziraat Fakultesi Dergisi 20(3): 118-125.

Ertekin I, Yılmaz Ş, Atak M, Can E, Çeliktaş N (2017) Tuz Stresinin Bazı Yaygın Fiğ (Vicia sativa L.) Çeşitlerinin Çimlenmesi Üzerine Etkileri. Mustafa Kemal Üniversitesi Ziraat Fakültesi Dergisi 22(2): 10-18.

Ertekin I, Yılmaz Ş, Atak M, Can E (2018) Effects of Different Salt Concentrations on the Germination Properties of Hungarian Vetch (Vicia pannonica Crantz.) Cultivars. Turkish Journal of Agricultural and Natural Sciences 5(2): 175-179.

Gao Y, Li D (2014) Growth responses of tall fescue (Festuca arundinacea Schreb.) to salinity stress. Eur. J. Hortic. Sci. 79(3): 123-128.

Kaplan M, Başer M, Kale H, Irık HA, Ülger I, Unlukara A (2017) Change in yield and chemical competition of tall fescue (Festuca arundinacea Schreb.) plants under salt stress. Turk. J. Field Crops 22(2): 204-210.

Kara B, Akgün i, Altındal D (2011) Tritikale genotiplerinde çimlenme ve fide gelişimi üzerine tuzluluğun $(\mathrm{NaCl})$ etkisi. Selçuk Tarım ve Gıda Bilimleri Dergisi 25(1): 1-9.

Kuşvuran A, Nazlı Ri, Kuşvuran Ş (2014). Salinity effects on seed germination in different tall fescue (Festuca arundinacea Schreb.) varieties. Tarım Bilimleri Araştırma Dergisi 7(2): 08-12. 
Kuşvuran A, Tansı V (2009) Çukurova koşullarına uygun çim tür ve karışımlarının belirlenmesi ve performanslarının saptanması. Çukurova Üniversitesi, Fen Bilimleri Enstitüsü, Tarla Bitkileri Anabilim Dalı, Doktora Tezi, Adana. 306s.

Li R, Bruneau AH, Qu R (2010) Morphological mutants of St. Augustinegrass induced by gamma ray irradiation. Plant Breed. 129(4): 412-416.

Manuchehri R, Salehi H (2015) Morphophysiological and biochemical changes in tall fescue (Festuca arundinacea Schreb.) under combined salinity and deficit irrigation stresses. Desert 20(1): 29-38.

Marcum KB (2006) Use of saline and non-potable water in the turfgrass industry: Constraints and developments. Agric. Water Manag. 80: 132-146.

Pawlowicz I, Waskiewicz A, Perlikowski D, Rapacz M, Ratajczak D, Kosmala A (2018) Remodelin chloroplast proteome under salinity effects salt tolerance of Festuca arundinacea. Photosynth. Res. 137: 475-492.
Richards LA (1954) Diagnosis and improvement of saline and alkali soils. U.S. Department Agriculture Handbook, No:60, February, Washington DC.

Sencer Ö, Gökmen S (1996) Tarımsal ekoloji, Gaziosmanpaşa Üniversitesi, Ziraat Fakültesi Yayınları, No:8, Tokat, $156 \mathrm{~s}$.

Sözen N, Haleplioğlu N, Şahin Ş (1991) Ülkemizde süs fidancılığının durumu ve pazar açısından karşılaşılan sorunlar. Türkiye 1. Fidancilık Sempozyumu. T.C. Tarım ve Köyişleri Bakanlığı, Ankara, 411-419s.

Suarez WMR, Olivera LAH (2016) Salinity tolerance in turfgrass speciess. Pastos y Forrajes 39(4): 219-228.

Trappe JM, Karcher DE; Richardson MD, Patton AJ (2011) Shade and traffic tolerance varies for bermudagrass and zoysiagrass cultivars. Crop Sci. 51(2): 870-877. 